УДК 544.6:57+606:628

Л.С. Зубченко, асист., ORCID 0000-0002-2549-3185

С.В. Кузьмінський, д-р. хім. наук, проф., ORCID 0000-0002-5632-8297

Національний технічний університет України «Київський політехнічний інститут імені Ігоря Сікорського»

\title{
БІОЕЛЕКТРОХІМІЧНІ АСПЕКТИ ВИБОРУ ФОТОЕЛЕКТРОХІМІЧНОЇ СКЛАДОВОЇ ФОТОБІОЕЛЕКТРОХІМІЧНИХ СИСТЕМ
}

В статті розглянуто можливість використання фотоелектрохімічних елементів як джерела енергї для фотобіоелектрохімічної системи. Мета роботи полягає в розгляді фото- та біоелектрохімічних прочесів, щзо відбуваються в фотобіоелектрохімічних системах, з точки зору оптимізації загальної продуктивності системи та теоретичному обтрунтуванні вибору матеріалу для фотоелектрохімічної складової фотобіоелектрохімічних систем. Проаналізовано реакції, щцо відбуваються в фотобіоелектрохімічних системах, які працюють за принципом чотирьохелектродної та двохелектродної системи, та потоки носіїв заряду, які беруть участь у формуванні струму в системі. Для визначення матеріалів, які найкраще підходять для використання в фотобіоелектрохімічних системах, проведено порівняльний аналіз найпоширеніших напівпровідників різних типів. Основними характеристиками напівпровідників, які враховували при визначенні придатності для поєднання 3 мікробним паливним елементом, були структура енергетичних рівнів та чутливість до світла у видимому спектрі. Визначено, щзо для використання в фотобіоелектрохімічній системі найкраще підходять $\mathrm{Si}$, $\mathrm{CdSe}, \mathrm{CuInS} \mathrm{S}_{2}, \mathrm{GaAs}, \mathrm{MoS}_{2}$ ma TaNO, CdS, $\mathrm{Cu}_{2} \mathrm{O}, \mathrm{GaP}, \mathrm{C}_{3} \mathrm{~N}_{4}, \mathrm{SiC}$.

Ключові слова: фотобіоелектрохімічна система, екзоелектрогени, фотоелектрохімічний елемент, напівпровідник, біоанод, заборонена зона

Вступ та постановка завдання. Морально застарілі та екологічно-небезпечні технології, які базуються на використанні викопного палива, з кожним роком поступаються новим відновлювальним джерелам енергії як в сегменті промислового виробництва, так і в побуті. Велика кількість відходів, яка утворюється в процесі виробництва та використання енергоносіїв, вироблених з нафти, газу та вугілля, та їх беззаперечний негативний вплив на довкілля робить пошук та впровадження нових енергетичних технологій та ресурсів ключовим завданням сьогодення. Низка міжнародних угод, зокрема Паризька кліматична угода, спрямована на забезпечення сталого розвитку на Землі, включають положення, що стосуються зменшення викидів парникових газів, основна маса яких утворюється при спалюванні викопного палива та продуктів його переробки. Тому використання нових нетрадиційних джерел енергії та їх розробка є актуальним питанням світової енергетики. Фотобіоелектрохімічні системи базуються на принципі поєднання двох видів альтернативних джерел енергії - фотоелектрохімічних елементів, які дозволяють асимілювати сонячну енергію, та біоелектрохімічних систем, які за рахунок біологічної складової здатні ефективно вилучати енергію, яка міститься в органічних речовинах відходів та стічних вод, та перетворювати їі у зручні для використання види енергоносіїв - електроенергію або водень.

Біоелектрохімічні системи (або мікробні паливні елементи) функціонують за рахунок життєдіяльності мікроорганізмів, які належать до специфічної групи електрохімічно-активних мікроорганізмів - екзоелектрогенів. У процесі життєдіяльності екзоелектрогени окиснюють органічні речовини шляхом анаеробного дихання, в результаті чого можуть генерувати і виділяти назовні клітини електрони і іони Гідрогену. В штучно створеній системі можливе перенесення цих електронів на анод мікробного паливного елемента (МПЕ), внаслідок чого в колі МПЕ протікає струм. В анаеробних умовах на катоді біоелектрохімічної системи (БЕХС) можливе виділення молекулярного водню, проте для забезпечення цього процесу важливою умовою є прикладання додаткової напруги в електричне коло для створення необхідного для утворення молекули водню електрохімічного потенціалу на катоді.

Для забезпечення незалежності біоелектрохімічної системи від зовнішніх енергетичних ресурсів запропоновано використовувати фотоелектрохімічні елементи або їх складові. Ці комбіновані системи отримали назву фотобіоелектрохімічні системи (ФБЕХС) або фотоелектрохімічні мікробні паливні елементи (ФМПЕ). Таким чином, фотобіоелектрохімічні системи (фотоелектрохімічні мікробні паливні елементи) - це системи, в яких енергія, яка отримана в результаті життєдіяльності електрохімічно-

(C) Л.С. Зубченко, С.В. Кузьмінський, 2018 


\section{ISSN 1813-5420 (Print). Енергетика: економіка, технології, екологія. 2018. № 1}

активних бактерій, поєднується з сонячною енергією, яка асимільована фотоелектрохімічним паливним елементом.

Процес утворення водню, який відбувається в фотобіоелектрохімічних системах, в загальних рисах нагадує аналогічний процес фоторозкладання води [1], проте його суттєвою відмінністю є використання молекул органічних речовин, а не води як джерела протонів.

Серед досліджень, які використовують фотоелектрохімічні елементи повністю, варто виділити ФБЕХС $з$ сенсибілізованими барвниками сонячними елементами (СБСЕ) $[2,3]$. Система складається 3 чотирьох електродів. Два електроди біоелектрохімічної системи: біоанод, виготовлений з вуглецевого матеріалу (паперу, тканини, волокна), з іммобілізованою на ньому біоплівкою електрохімічно-активних мікроорганізмів та катод, на якому відбувається відновлення водню. Фотоелемент також має два електроди: фотокатод, виготовлений з фоточутливого матеріалу, та металевий анод.

В СБСЕ фотокатод виготовлений 3 оксиду титану, покритого світлочутливим барвником, (наприклад, поліпіридильним комплексом рутенію, осмію або стануму) [2, 3]. Під дією світла електрони в молекулах барвника переходять у збуджений стан і рекомбінують 3 дірками, утвореними в діоксиді титану внаслідок фотоефекту. Через внутрішній шар, який заповнений редокс парою йодид-трийодид, електрони переходять на робочий електрод сонячного елемента, звідки - на катод БЕХС. Електрони, які генерують електрохімічно-активні мікроорганізми на біоаноді, в свою чергу, заміщують електрони, які утворилися при збудженні барвника світлом. Додаткова напруга, яка генерується сонячним елементом, зменшує потенціал катода БЕХС до рівня, при якому відновлення водню стає термодинамічно можливим.

Новий підхід до вирішення проблеми додаткового джерела енергії запропоновано в [4]. ФБЕХС складається 3 мікробного паливного елемента та фотоелектрохімічного елемента. Мікробний паливний елемент виготовлений у вигляді двокамерного реактора, розділеного протонпроникною мембраною, 3 біоанодом 3 вуглецевої тканини, та катодом, виготовленим 3 вуглецевої тканини 3 електрохімічно іммобілізованими частинками платини (Рис 1.). Фотоелектрохімічний елемент - однокамерна система 3 фотоанодом з діоксиду титану (напівпровідник n-типу) та платиновим катодом. Особливістю системи $є$ те, що біоанод з'єднаний з катодом фотоелемента, а фотоанод з катодом мікробного паливного елемента. Виділення водню відбувається на катоді фотоелемента за участі електронів, які генерують мікроорганізми на біоаноді мікробного паливного елемента. На фотоаноді відбувається реакція фоторозкладання води 3 утворенням атомів кисню та протонів. Суттєвим недоліком описаної системи є утворення кисню і водню в одній камері, що призводить до утворення вибухонебезпечних сумішей.

(a)

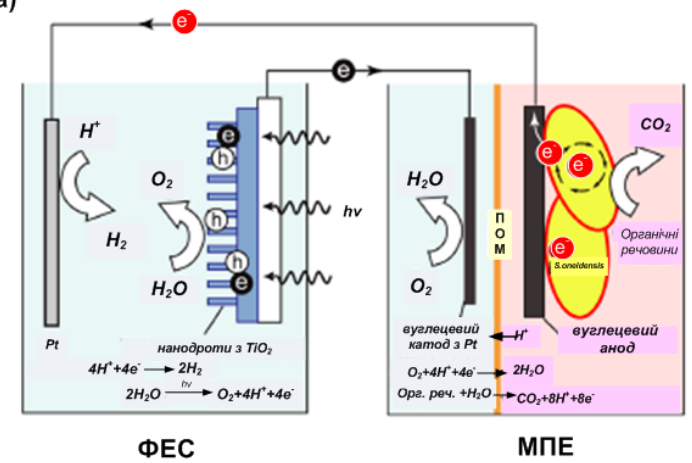

(б)

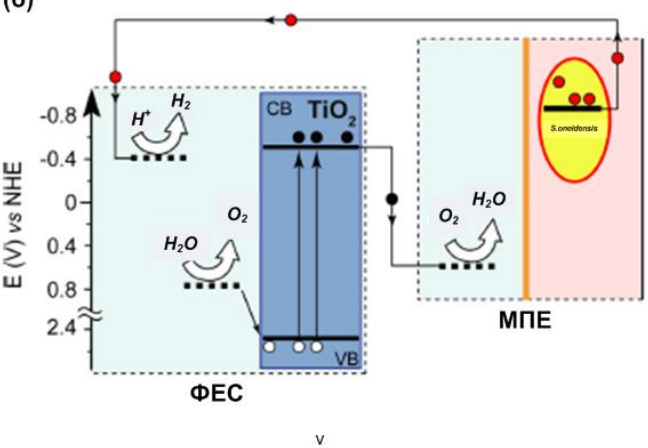

Рисунок 1 - a - схема функціонування ФБЕХС [4]; 6 - схема розміщення енергетичних рівнів та перенесення електронів у ФБЕХС з фотокатодом з $\mathrm{TiO}_{2}$

В багатьох дослідженнях розглядається поєднання біоелектрохімічної системи 3 окремим фотокатодом. Використання лише фотокатода дозволяе спростити систему - перетворити 3 чотирьохелектодної (біоанод i катод біоелектрохімічної системи та фотокатод та анод фотоелектрохімічної системи) в двохелектродну (біоанод i фотокатод). Можливе використання напівпровідників n- i p- типу. Виділення водню відбувається безпосередньо на поверхні фотокатода, зануреного в безкисневий електроліт, при цьому роль p-n переходу виконує межа поділу фаз напівпровідник/катодний розчин $[1,5]$.

Розроблена в [6] фотобіоелектрохімічна система складається з біоанода, виготовленого з вуглецевої тканини з іммобілізованою біоплівкою, яка сформована 3 чистої культури електрохімічно-активних 
мікроорганізмів Shewanella oneidensis MR-1, та фотокатода, виготовленого 3 оксиду Купруму $\mathrm{Cu}_{2} \mathrm{O}$ (Рис.2 (a)). Оксид Купруму є напівпровідником р-типу з шириною забороненої зони 2,2 еВ та структурою енергетичних зон: - 0,69 В - зона провідності, $1,51 \mathrm{~B}$ - валентна зона. Для збільшення площі поверхні фотокатод виготовлений у вигляді пластини, покритої нанодротами.

При освітленні фотокатода світлом з енергією квантів більшою за ширину забороненої зони, електрони набувають енергію, яка достатня для переходу їх в зону провідності напівпровідника. Оскільки в напівпровідниках р-типу основними носіями заряду є дірки, то струм, який виникає в фотокатоді, протікає за рахунок дірок. Електрони ж, виконуючи роль неосновних носіїв заряду, відновлюють водень на межі поділу фаз фотокатод/катодний розчин. Біоанод в даному випадку виступає протиелектродом, потенціал якого зумовлюється біохімічними реакціями, які здійснюють електрохімічно-активні мікроорганізми в процесі анаеробного окиснення органічних речовин.

Для використання напівпровідникових матеріалів в ФБЕХС важливе значення має розподіл енергетичних рівнів напівпровідника. В такій гібридній ФБЕХС енергія нижнього краю зони провідності близька до - 0,69 В, що забезпечує можливість відновлення водню на межі поділу фаз фотокатод/катодний розчин [6]. Значення потенціалу анода визначається потенціалом реакції окиснення органічної речовини та потенціалом цитохромів на зовнішній мембрані клітин електрохімічно-активних мікроорганізмів. Для описаної системи значення потенціалу анода більш негативне $(-0,3$ В) ніж значення енергії верхнього краю валентної зони фотокатода, в якій зосереджуються дірки. Така різниця потенціалів електродів робить можливим протікання струму в зовнішньому колі за рахунок електронів, утворених електрохімічноактивними мікроорганізмами. Схема розподілу енергетичних рівнів та переносу електронів в ФБЕХС 3 $\mathrm{Cu}_{2} \mathrm{O}$ - фотокатодом зображена на рис. 2(б).
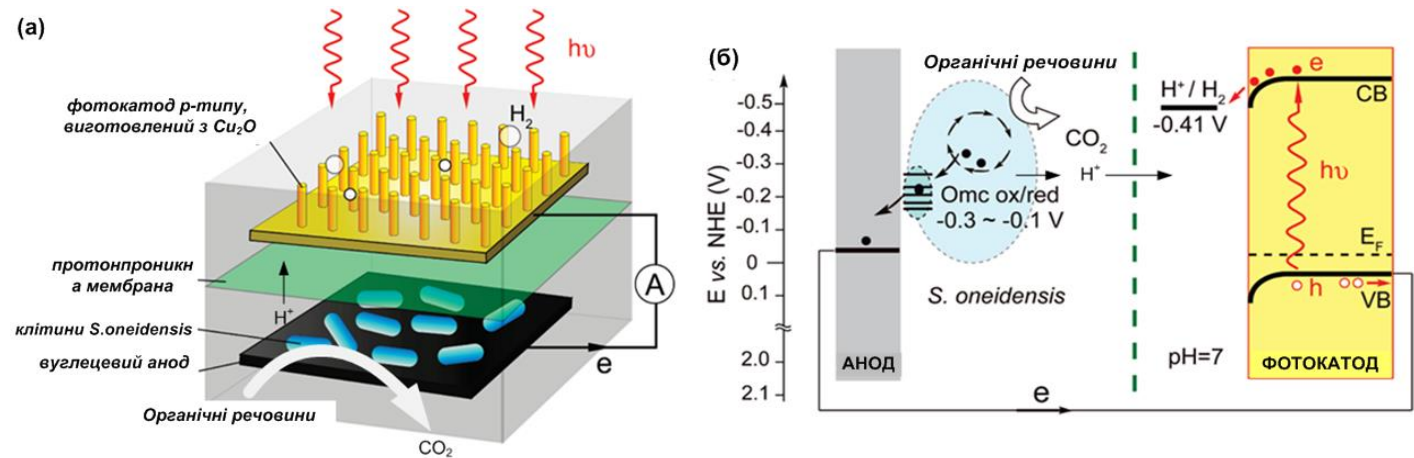

Рисунок 2- а - схема функціонування ФБЕХС [6]; б - схема розміщення енергетичних рівнів та перенесення електронів у ФБЕХС з фотокатодом з $\mathrm{Cu}_{2} \mathrm{O}$

Проте, не лише напівпровідники р-типу використовують як фотокатоди. Успішне використання $\mathrm{TiO}_{2}$ (рутилу), показано в $[7,8] . \mathrm{TiO}_{2}$ - напівпровідник n-типу з шириною забороненої зони 3,2-3,35 еВ. При поєднанні його з біоанодом, на якому іммобілізовані клітини Shewanella oneidensis MR1, продемонстровано виділення водню. Причому в експерименті показано, що отримати водень в системі біоанод-фотокатод можливо лише при виконанні трьох умов: наявності мікроорганізмів, субстрату та при опромінення фотокатода світлом.

Окрім двох- та чотириелектродних фотобіоелектрохімічних систем існують також триелектродні, які складаються з двох електродів біоелектрохімічної системи (біоанод та катод) та фотоелектрода (зазвичай $\mathrm{n}$-типу). Проте, такі системи зазвичай використовують для отримання не водню, а електроенергії. Оскільки продуктивність біоелектрохімічних систем часто лімітується швидкістю рекомбінації молекул на катоді мікробного паливного елемента, в багатьох випадках для підвищення швидкості реакції утворення молекули води достатньо зменшити потенціал катода. 3 цією метою в роботі використано послідовно підключений фотокатод, виготовлений з напівпровідника n-типу. Електрони, які генеруються при опроміненні напівпровідникового фотокатода світлом і надходять в зовнішнє електричне коло, значно знижують окисно-відновний потенціал катода біоелектрохімічної системи, що сприяє підвищенню швидкості катодної реакції. Особливий інтерес при дослідженні роботи триелектродних ФБЕХС викликають побічні процеси, які можуть відбуватися на фотокатоді. Наприклад, при використанні фотоелектрода з титану диоксиду, з'єднаного з біоанодом, можливе отримання метану з $\mathrm{CO}_{2}$ [9].

Загалом, система працює як біоелектрохімічна система для отримання електричної енергії, яка складається 3 двох електродів мікробного паливного елемента та фотокатода 3 напівпровідника n-типу $\mathrm{TiO}_{2}$, під'єднаного в зовнішне електричне коло МПЕ. Фотострум, який виникає в фотокатоді при 


\section{ISSN 1813-5420 (Print). Енергетика: економіка, технології, екологія. 2018. № 1}

освітленні, надходить в коло мікробного паливного елемента. Зменшення потенціалу катода сприяє збільшенню швидкості рекомбінації протонів з молекулами кисню. В напівелемент фотокатода подають вуглекислий газ. На межі поділу фаз відбувається реакція утворення метану з вуглекислого газу та води. Електрони, які утворюються в цій реакції, заміщують дірки в валентній зоні фотокатода.

Подібний принцип роботи і у фотобіоелектрохімічної системи, в якій, окрім генерування електричної енергії, відбувається руйнування барвника метиленового синього [10]. В однокамерному МПЕ біоанод з'єднаний з катодом та додатково з фотокатодом. Руйнування метиленового синього відбувається як за рахунок діяльності мікроорганізмів, так і за рахунок взаємодій з продуктами вільнорадикальних реакцій, що утворюються на фотокатоді при збудженні напівпровідника світлом.

Таким чином, використання фотоелектрохімічних систем чи їх окремих складових знайшло широке застосування в технології мікробних паливних елементів і має великий потенціал для подальших досліджень.

Серед основних проблем, які виникають при розробці фотобіоелектрохімічних систем важливе місце посідає вибір матеріалу напівпровідника.

Мета роботи полягає в аналізі фото- та біоелектрохімічних процесів, що відбуваються в фотобіоелектрохімічних системах, 3 точки зору оптимізації загальної продуктивності системи та теоретичному обгрунтуванні вибору матеріалу для фотоелектрохімічної складової фотобіоелектрохімічних систем.

\section{Результати та обговорення}

Як зазначалося, відновлення водню на катоді біоелектрохімічної системи можливе лише за використання додаткового джерела енергії, оскільки електронів, які генерують електрохімічно-активні мікроорганізми, що іммобілізовані на аноді, не вистачає для забезпечення електрохімічного потенціалу, необхідного для відновлення водню. Неможливість самочинного утворення водню в біоелектрохімічній системі випливає з термохімічних розрахунків, зокрема з розрахунку зміни вільної енергії Гіббса.

За використання ацетату натрію як поживного субстрату реакція, яку здійснюються електрохімічно-активні мікроорганізми на аноді буде описуватися рівнянням:

$$
\mathrm{CH}_{3} \mathrm{COO}^{-}+2 \mathrm{H}_{2} \mathrm{O} \rightarrow 2 \mathrm{CO}_{2}+7 \mathrm{H}^{+}+8 e^{-} .
$$

Катодна реакція відновлення водню:

$$
8 H^{+}+8 e^{-}=4 H_{2} .
$$

Тоді сумарна реакція має вигляд:

$$
\mathrm{CH}_{3} \mathrm{COO}^{-}+2 \mathrm{H}_{2} \mathrm{O}+\mathrm{H}^{+} \rightarrow 2 \mathrm{CO}_{2}+4 \mathrm{H}_{2} \text {. }
$$

Зміну енергію Гіббса для реакції утворення водню з ацетату можна розрахувати за наступним рівнянням[11]:

$$
\Delta G=\Delta H-T \cdot \Delta S,
$$

де $\Delta H$ - зміна ентальпії реакції утворення водню з ацетату, яка розраховується за формулою:

$$
\Delta H=\left(4 \cdot \Delta H_{298 H_{2}}^{\circ}+2 \cdot \Delta H_{298 C_{2}}^{\circ}\right)-\left(\Delta H_{298}^{\circ} \mathrm{CH}_{3} \mathrm{COO}^{-}+2 \cdot \Delta H_{298 \mathrm{H}_{2} \mathrm{O}}^{\circ}\right) ;
$$

$\Delta S$ - зміна ентропії реакції утворення водню з ацетату, яка розраховується за формулою:

$$
\Delta S=\left(4 \cdot S_{298 H_{2}}^{\circ}+2 \cdot S_{298 C_{2}}^{\circ}\right)-\left(S_{298}^{\circ} \mathrm{CH}_{3} \mathrm{COO}^{-}+2 \cdot S_{298 \mathrm{H}_{2} \mathrm{O}}^{\circ}\right) .
$$

В таблиці 1 наведені стандартні ентальпії та ентропії утворення продуктів та вихідних речовин для реакції 3, та розраховані значення зміни ентальпії та ентропії цієї ж реакції відповідно до (5) і (6).

Таблиця 1 - Стандартні ентропії та ентальпії утворення продуктів і реагентів [12] для реакції отримання водню з ацетату

\begin{tabular}{|l|l|l|}
\hline Речовина & $\Delta \mathrm{H}_{298}^{\circ}$, кДж/моль & $\mathrm{S}_{298}^{\circ}$, Дж/(моль $\left.\cdot \mathrm{K}\right)$ \\
\hline $\mathrm{H}_{2}$ & 0 & 130,59 \\
\hline $\mathrm{CO}_{2}$ & $-393,511$ & 213,65 \\
\hline $\mathrm{H}_{2} \mathrm{O}($ рід. $)$ & $-285,84$ & 69,96 \\
\hline $\mathrm{CH}_{3} \mathrm{COO}^{-}$ & $-485,64$ & 87,58 \\
\hline & $\Delta \mathrm{H}=270,298$, кДж/моль & $\Delta \mathrm{S}=772,16$, Дж/(моль $\cdot \mathrm{K})$ \\
\hline
\end{tabular}


Підставляючи отримані значення $\Delta \mathrm{H}$ та $\Delta \mathrm{S}$ в рівняння (4), отримуємо значення зміни вільної енергії Гіббса для реакції утворення водню, яке становить:

$$
\Delta G=\Delta H-T \cdot \Delta S=270,298 \cdot 10^{3}-298 \cdot 772,16=55094,32, \text { Дж/моль. }
$$

Позитивне значення зміни вільної енергії Гіббса свідчить про те, що за даних умов реакція самочинно відбуватися не буде, тобто для отримання водню в біоелектрохімічній системі потрібно долучати додаткову енергію.

Для того, щоб визначити значення напруги у колі біоелектрохімічної системи, яке необхідне для забезпечення процесу відновлення водню на катоді, можна скористатися рівнянням Нернста.

Визначити окисно-відновний потенціал електрода за рівнянням Нернста можна використовуючи наступний вираз:

$$
E=E^{0}+\frac{R T}{n F} \ln \frac{a_{O \kappa}}{a_{B i \partial}},
$$

де $E$ - електродний потенціал для умов, за яких відбувається реакція, В; $E^{0}$ - стандартний електродний потенціал, $\mathrm{B} ; \quad R=8,31$ - універсальна газова стала, Дж/(моль $\mathrm{K}) ; T$ - абсолютна температура, К; $n$ - число електронів, що бере участь у реакції, $F=96485$ - стала Фарадея, Кл/моль; $a_{O \kappa}$. - активність окисненої форми речовини; $a_{\text {вid }}$. - активність відновленої форми речовини.

За умови, що на катоді відбувається реакція відновлення водню, окисно-відновний потенціал катода при $\mathrm{pH} 7$ і тиску водню $p_{H_{2}}=1$ атм буде визначатися як:

$$
E_{H^{+} / H_{2}}=E_{H^{+} / H_{2}}^{0}+\frac{R T}{2 \cdot F} \ln \frac{\left[H^{+}\right]^{2}}{p H_{2}}=0+\frac{8,31 \cdot 298}{2 \cdot 96485} \ln \frac{\left[10^{-7}\right]^{2}}{1}=-0,414 .
$$

Відповідно до літературних даних [13], окисно-відновний потенціал напівреакції окиснення ацетату до $\mathrm{CO}_{2}$ становить $-0,29$ В. Тоді електрорушійна сила біоелектрохімічної системи, в якій відбувається окиснення ацетату з утворенням водню, буде розраховуватися за формулою:

$$
E P C=E_{\kappa a m}-E_{a H}=E_{H^{+} / H_{2}}-E_{\mathrm{CO}_{2} / \mathrm{CH}_{3} \mathrm{COO}^{-}}=-0,414-(-0,29)=-0,124 B .
$$

Тобто теоретичне додаткове значення напруги, яке необхідне для виділення водню на катоді біоелектрохімічної системи, становить $-0,124$ В. Враховуючи, що певна частина енергії, отриманої в процесі окиснення ацетату електрохімічно-активними мікроорганізмами, витрачається на власні енергетичні потреби клітини, потенціал біоанода зазвичай менш негативний, ніж теоретично розрахований, і находиться в межах від - 0,2 В до - 0,28 В [14]. Виходячи з цього, додаткова напруга, яку необхідно прикласти для забезпечення виділення водню на катоді біоелектрохімічної системи, становить від $-0,13$ В до $-0,21 \mathrm{~B}$.

Менше значення анодного потенціалу також пов'язане 3 тим, що процес окиснення ацетату відбувається не безпосередньо на аноді, а всередині клітин електрохімічно-активних мікроорганізмів, частина його втрачається при перенесенні електронів з клітини назовні та від зовнішньої мембрани до анода. При прямому перенесенні електрона від клітини до анода для забезпечення функції перенесення електронів потенціал цитохромів зовнішньої мембрани має бути більший від окисно-відновного потенціалу реакції окиснення ацетату ( $-0,3 \div-0,1$ В для Shewanella oneidensis) [6]. Медіатори, як штучні, так і ті, які клітини синтезують самостійно, «транспортують» електрони від первинних акцепторів в клітинах мікроорганізмів, таких як НАДН (- 0,32 В), ферредоксину $(-0,42$ В), глутатіону $(-0,24$ В), до анода біоелектрохімічної системи $[15,16]$. Найбільш поширеними сполуками, які мають властивості медіаторів, є похідні феназину [15], окисно-відновний потенціал яких коливається в широких межах i становить від - 0,032 В [16] до - 0,34 В [17] (для похідних феназину, які синтезують Pseudomonas aeruginosa) і загалом є більш позитивним, ніж окисно-відновний потенціал первинних акцепторів електронів. Високе значення окисно-відновного потенціалу медіаторів сприяє перенесенню електронів назовні клітини, проте часто значно знижує потенціал анода та загальну продуктивність системи за струмом.

Для ефективної роботи фотобіоелектрохімічної системи матеріал, 3 якого виготовлений фотокатод, повинен мати підходящу для компонування 3 мікробним паливним елементом структуру енергетичних рівнів. Зокрема, енергія нижнього краю зони провідності має бути більш негативною ніж електрохімічний потенціал відновлення водню на катоді (- 0,414 В). Крім того, важливо, щоб енергія верхнього краю валентної зони була більш позитивною, ніж потенціал анода $(-0,2 \mathrm{~B}-(-0,28)$ В). Значення окисно-відновного потенціалу анода, в свою чергу, залежить від значення окисно-відновного потенціалу 


\section{ISSN 1813-5420 (Print). Енергетика: економіка, технології, екологія. 2018. № 1}

реакції окиснення субстрату та виду перенесення електронів до анода. При прямому перенесенні електронів від клітин до анода визначальним буде потенціал цитохромів зовнішньої мембрани клітин електрохімічно-активних мікроорганізмів, а при опосередкованому перенесенні (перенесення за допомогою медіаторів) - потенціал окиснення розчинних медіаторів

На рис. 3 наведена характеристика розподілу енергетичних рівнів у напівпровідниках різних типів.

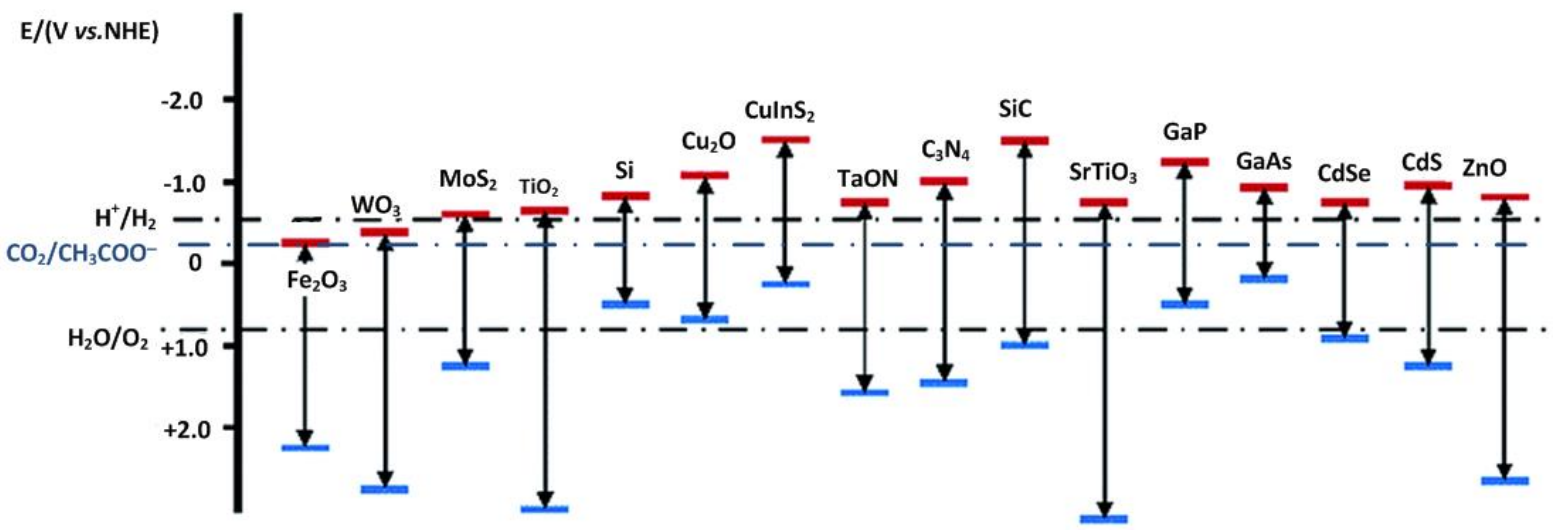

Рис. 3 Характеристика розподілу енергетичних рівнів у напівпровідниках [18]

Виходячи з вищенаведеного, серед найбільш поширених напівпровідників для використання в фотобіоелектрохімічних системах підходять $\mathrm{Si}, \mathrm{Cu}_{2} \mathrm{O}, \mathrm{TiO}_{2}, \mathrm{ZnO}, \mathrm{CdS}, \mathrm{TaNO}, \mathrm{MoS}_{2}, \mathrm{CuInS}_{2}, \mathrm{C}_{3} \mathrm{~N}_{4}, \mathrm{SiC}, \mathrm{GaP}$, GaAs, CdS.

Важливою характеристикою при виборі фоточутливого матеріалу $є$ ширина забороненої зони напівпровідника. Генерування носіїв заряду в напівпровіднику відбувається при освітленні світлом 3 енергією квантів більшою ніж ширина забороненої зони. Оскільки енергія фотона залежить від довжини хвилі світла, то, знаючи ширину забороненої зони напівпровідника, можна визначити довжини хвиль, при яких у ньому буде виникати явище фотоефекту. Енергію фотона можна розрахувати за формулою:

$$
\varepsilon=h v=h \frac{c}{\lambda}
$$

де $\varepsilon$ - енергія фотона; $v$ - частота світлової хвилі; $h=0,4139 \cdot 10^{-16}$ - стала Планка, еВ·с, $\left(6,63 \cdot 10^{-34}\right.$, Дж·c); $c=3 \cdot 10^{8}$ - швидкість світла, м/с; $\lambda$ - довжина хвилі світла, м.

Тоді, якщо виразити ширину забороненої зони як енергію світлового випромінювання, то напівпровідник буде чутливий до світла з довжиною, меншою за $\lambda$, розрахувати яку можна за формулою:

$$
\lambda=\frac{h c}{\varepsilon}=\frac{1,24 \cdot 10^{-6}}{\varepsilon}, \mathrm{eB} .
$$

У таблиці 2 приведені значення енергії, яка характеризує ширину забороненої зони для напівпровідникових матеріалів, які найчастіше використовуються для виготовлення фотоелементів, та максимальні значення довжини хвилі, при яких матеріал фоточутливий.

Таблиця 2 - Значення енергії, яка характеризує ширину забороненої зони [18], та довжини хвиль світла, які

\begin{tabular}{|c|c|c|c|c|c|c|c|c|}
\hline Матеріал & $\mathrm{E}_{33, \mathrm{eB}}$ & $\lambda$, нM & Матеріал & $\mathrm{E}_{33, \mathrm{eB}}$ & $\lambda, \mathrm{HM}$ & Матеріал & $\mathrm{E}_{33, \mathrm{eB}}$ & $\lambda, \mathrm{HM}$ \\
\hline CdSe* $^{*}$ & 1,7 & 729 & $\mathrm{ZnO}$ & 3,3 & 376 & GaP** & 2,25 & 551 \\
\hline $\mathrm{Fe}_{2} \mathrm{O}_{3} * *$ & 2,1 & 590 & $\mathrm{CdS}^{* *}$ & 2,4 & 517 & InSb* & 0,17 & 7294 \\
\hline $\mathrm{WO}_{3} * *$ & 2,6 & 477 & TaNO** & 2,4 & 517 & $\mathrm{Ge}^{*}$ & 0,66 & 1879 \\
\hline $\mathrm{Bi}_{2} \mathrm{WO}_{6} * *$ & 2,8 & 443 & $\mathbf{S i}^{*}$ & 1,1 & 1127 & $\mathrm{C}_{3} \mathbf{N}_{4} * *$ & 2,7 & 459 \\
\hline $\mathrm{BiVO}_{4} * *$ & 2,4 & 517 & $\mathrm{Cu}_{2} \mathbf{O} * *$ & 2,2 & 564 & $\mathbf{S i C}^{* *}$ & 3 & 413 \\
\hline $\mathrm{TiO}_{2}$ & 3,2 & 388 & GaAs* & 1,4 & 886 & $\mathrm{MoS}_{2}$ * & 1,75 & 709 \\
\hline $\mathrm{CuInS}_{2} *$ & $1,1-2,5$ & $1127-496$ & $\mathrm{SrTiO}_{3}$ & 3,2 & 388 & & & \\
\hline
\end{tabular}
мають відповідну енергію

*матеріали, активні в усій області видимого світла;

** матеріали, активні в частині області видимого світла;

жирним шрифтом виділені матеріали, які підходять для використання в фотобіоелектрохімічних системах за зонною структурою. 
Сонячне світло має довжини хвиль в діапазоні $10 \div 2000$ нм, причому видима частина спектру включає хвилі 3 довжиною $390 \div 750$ нм, ультрафіолетова $100 \div 400$ нм, інфрачервона 750 нм $\div 2000$ мкм. Сонячне випромінювання, яке досягає поверхні Землі, має довжини хвиль, які знаходяться в інфрачервоному діапазоні ( $50 \%$ ) та області видимого світла ( $240-45 \%)$, решта припадає на ультрафіолетове випромінювання [19]. Тому фоточутливість матеріалу в видимій та інфрачервоній області спектру є одним з факторів, що зумовлюють вибір напівпровідника для фотобіоелектрохімічних систем.

Відповідно до даних, приведених в таблиці 2 та на рис. 3, оптимальними, з точки зору ефективності світлопоглинання в видимій області спектру сонячного випромінювання та відповідності зонної структури матеріалу окисно-відновним реакціям біоелектрохімічної системи, $€$ наступні напівпровідникові матеріали: $\mathrm{CdSe}, \mathrm{CuInS}_{2}, \mathrm{Si}, \mathrm{GaAs}, \mathrm{MoS}_{2}$, які мають здатність поглинати світло в усьому видимому діапазоні, та TaNO, $\mathrm{CdS}, \mathrm{Cu}_{2} \mathrm{O}, \mathrm{GaP}, \mathrm{C}_{3} \mathrm{~N}_{4}, \mathrm{SiC}$, які $є$ активними не в усій області спектру видимого світла.

При виборі матеріалу для виготовлення фотоелектрохімічних елементів керуються зазвичай значенням ККД для матеріалу, вартістю, простотою виготовлення та експлуатації матеріалу, а також стабільністю роботи елемента протягом терміну експлуатації.

Серед відомих на сьогодні матеріалів для виготовлення фотоелементів в широкий вжиток увійшли кремнієві фотоелементи та тонкоплівкові, до яких входять фотоелементи на основі аморфного кремнію (а$\mathrm{Si}$ ), $\mathrm{CdTe}, \mathrm{CuInGaSe}$, GaAs, InP, CdSe, $\mathrm{Cu}_{2} \mathrm{Se}, \mathrm{Cu}_{2} \mathrm{O}$ та ін. До тонкоплівкових також відносять сенсибілізовані барвниками сонячні елементи. Тонкоплівкові ФЕС мають найменшу вартість серед матеріалів, проте ККД для них не перевищує 5-12\%, а отже, в порівнянні з іншими матеріалами, вони потребують значно більшої площі для розміщення робочих модулів [20, 21].

Для кремнієвих ФЕС ККД становить 15-17\% для полікристалічного кремнію і до 22\% для монокристалічного кремнію [20, 21].

Не зважаючи на вищу вартість, 80 \% світового ринку сонячних батарей займають фотоелементи на основі кристалічного кремнію. Причому зазвичай виробники віддають перевагу полікристалічному, оскільки нижчий ККД зазвичай компенсується більшою стабільністю роботи при розсіяному світлі, меншою вартістю та простішою технологією виробництва.

Висновки. Використання фотоелектрохімічних елементів як джерела додаткової енергії в біоелектрохімічних системах для отримання водню $є$ перспективним шляхом розвитку для цієї галузі біоенергетики. Поєднання сонячної енергії, асимільованої фотоелектрохімічним елементом, 3 енергією, яку електрохімічно-активні мікроорганізми генерують в процесі метаболічного перетворення органічних речовин, забезпечує автономне, незалежне від зовнішніх джерел енергії, функціонування фотобіоелектрохімічної системи.

Практично всі типи фоточутливих матеріалів можуть бути використані в технології фотобіоелектрохімічних систем. Проте, для забезпечення максимальної продуктивності та бажаного економічного ефекту, вибір фотоелектрохімічного елемента має базуватися на основі аналізу технологічних, фізико-хімічних та економічних показників фоточутливих матеріалів.

На основі даних, представлених в статті, найкраще для використання в фотобіоелектрохімічних системах підходять $\mathrm{Si}, \mathrm{CdSe}, \mathrm{CuInS}_{2}, \mathrm{GaAs}, \mathrm{MoS}_{2}$ та TaNO, CdS, Cu $\mathrm{Cu}_{2} \mathrm{O}, \mathrm{GaP}, \mathrm{C}_{3} \mathrm{~N}_{4}, \mathrm{SiC}$. Зважаючи на вищезазначені переваги використання та поширеність, кристалічний кремній і арсенід галію є ідеальним варіантами для фотоактивної складової фотобіоелектрохімічних систем.

\section{Список використаної літератури}

1 Зубченко Л.С. Світлозалежне отримання водню в паливних та біопаливних елементах / Л. С. Зубченко, С. В. Кузьмінський // Відновлювальна енергетика. - 2015. - Вип. 4. - С. 85-92.

2. Ajayi F. F. Study of hydrogen production in light assisted microbial electrolysis cell operated with dye sensitized solar cell / F. F. Ajayi, K. Y. Kim, K.-J. Chae, M. J. Choi, S. Y. Kim, I. S. Chang, I. S. Kim // International Journal of Hydrogen Energy.- 2009. - Vol. 34, №. 23.- P. 9297-9304.

3. Ajayi F. F. Optimization studies of bio-hydrogen production in a coupled microbial electrolysis-dye sensitized solar cell system / F. F. Ajayi, K. Y. Kim, K. J. Chae, M. J. Choi, S. Y. Kim, I. S. Chang, I. S. Kim // Photochemical photobiological sciences:Official journal of the European Photochemistry Association and the European Society for Photobiology. - 2010. - Vol. 9, - №. 3.- P. 349-356.

4 Wang H. Self-biased solar-microbial device for sustainable hydrogen generation / H. Wang, F. Qian, G. Wang, Y. Jiao, Z. He, Y. Li // ACS Nano. - 2013. - Vol. 7. - № 10. - P. 8728-8735. 
5. Кузьмінський $€$. В. Нетрадиційні електрохімічні системи перетворення енергії. Фото-, термо- та біопаливні елементи: Навчальний посібник. / Є. В Кузьмінський., Г. Я. Колбасов, Я. Ю. Тевтуль, Н. Б. Голуб. -Чернівці : Рута, - 2003.-96с.

6. Qian F. Solar-driven microbial photoelectrochemical cells with a nanowire photocathode / F. Qian, G. Wang, Y. Li // NanoLett. - 2010. - № 10.- P 4686-4691.

7. Lu A. Microbial fuel cell equipped with a photocatalytic rutile-coated cathode / A. Lu, Y. Li, S. Jin, H. Ding, C. Zeng, X. Wang, C. Wang // Energy Fuels. - 2009. - №24 (2). -P. 1184-1190.

8. Chen Q.Y. Hydrogen production on $\mathrm{TiO}_{2}$ nanorod arrays cathode coupling with bio-anode with additional electricity generation/ Q.Y. Chen, J. S. Liu, Y. Liu, Y.H. Wang// Journal of Power Sources. - 2013. № 238. - P. 345-349.

9. Kim H. W. Photocoupled bioanode: a new approach for improved microbial fuel cell performance / H. W. Kim, K. S. Lee, A. Razzaq, S. H. Lee, C. A. Grimes, S. I. In // Energy Technol. - 2018. - Vol. 6. P. $257-262$.

10. Lee S. H. Wastewater treatment and electricity generation from a sunlight-powered single chamber microbial fuel cell / S. H. Lee, K. S. Lee, S. Sorcar, A. Razzaq, C. A. Grimes, S. I. In // Journal of Photochemistry and Photobiology A: Chemistry. $-2017 .-9$ p.

11. Kuzminskiy Ye. Bioelectrochemical hydrogen and electricity production. Theoretical bases, description and modeling of the process. / Ye. Kuzminskiy, K. Shchurska, I. Samarukha, G. Lagod. - Lublin : Politechnica Lubelska, $-2013 .-102 \mathrm{p}$.

12. Глушко В. П. Термические константы веществ / Под ред. В. П. Глушко, - М. : ВИНИТИ, - 19651982. - Вып.1-10.

13. Yan J. Handbook of clean energy systems: 6 volume set / J. Yan. - Chichester: John Wiley \& Sons, 2015. - Vol. 5. $-4032 \mathrm{p}$.

14 Logan B. E. Microbial fuel cells: methodology and technology / B. E. Logan, B. Hamelers, R. Rozendal, U. Schröder, J. Keller, S. Freguia, P. Aelterman, W. Verstraete, K. Rabaey // Environ. Sci. Technol. - 2006. - Vol. 40 (17). - P. 5181-5192.

15 Rabaey K. Microbial phenazine production enhances electron transfer in biofuel cells / K. Rabaey, N. Boon, M. Höfte, W. Verstraete // Environ. Sci. Technol. - 2005. - Vol. 39 (9). - P. 3401-3408.

16. Price-Whelan A. Pyocyanin alters redox homeostasis and carbon flux through central metabolic pathways in Pseudomonas aeruginosa PA14 / A. Price-Whelan, L. E. P. Dietrich, D. K. Newman // J. Bacteriol. 2007. - Vol. 189. - № 17. - P. 6372-6381.

17. Dietrich L. E. P. The phenazine pyocyanin is a terminal signaling factor in the quorum sensing network of Pseudomonas aeruginosa / L. E. P. Dietrich, A. Price-Whelan, A. Petersen, M. Whiteley, D. K. Newman // Molecular Microbiology. - 2006. - Vol. 61(5). - P. 1308-1321.

18. Zhao J. Hybrid catalysts for photoelectrochemical reduction of carbon dioxide: a prospective review on semiconductor/metal complex co-catalyst systems / J. Zhao, X. Wang, Z. Xu and J. S. C. Loo// Journal of Materials Chemistry A. - 2006. - vol. 2 - Is. 37. - P. 15228-15233.

19. Мусієнко М. М. та ін. Екологія: Тлумачний словник. - К.: Либідь, 2004. -376 с.

20. Фреїк Д. М. Фотоелектричні перетворювачі сонячного випромінювання. Досягнення, сучасний стан і тенденції розвитку / Д. М. Фреїк, В. М. Чобанюк, М. О. Галущак, О. С. Криницький, Г. Д. Матеїк // Фізика і хімія твердого тіла. - 2012. - Т. 13. - №1. - С. 7-20.

21. Кожем'яко В. П. Аналітичний огляд сучасних технологій фотоелектричних перетворювачів для сонячної енергетики / В. П. Кожем'яко, О. Г. Домбровський, В. Ф. Жердецький, В. І. Маліновський, Г. В. Притуляк // Оптико-електронні інформаційно-енергетичні технології. - 2011. - т. 22. - №20. - С. 141 - 157.

УДК 544.6:57+606:628

Л.С. Зубччено, асс., ORCID 0000-0002-2549-3185

Є.В. Кузьминский, д-р. хим. наук, проф., ORCID 0000-0002-5632-8297

Национальный технический университет Украины «Киевский политехнический институт имени Игоря Сикорского» БИОЕЛЕКТРОХИМИЧЕСКИЕ ОСНОВЫ ВЫБОРА ФОТОКАТОДА ДЛЯ ФОТОБИОЕЛЕКТРОХИМИЧЕСКОЙ СИСТЕМЫ

В статье рассмотрена возможность использования фотоэлектрохимических элементов, как источника дополнительной энергии для фотобиоэлектрохимической системы. Цель работы заключается в анализе фото- и биоэлектрохимических проиессов, происходящих в фотобиоэлектрохимических системах с точки зрения оптимизации общей производительности системь и теоретическое обоснование выбора материала для фотоэлектрохимической составляющей фотобиоэлектрохимических систем. Проанализированы биоэлектрохимические и фотоэлектрохимические реакиии, происходящие 8 
фотобиоэлектрохимических системах, работающих по принцииу четырехэлектродной $u$ двухэлектродной системы и потоки носителей заряда, участвующие в формировании тока в системе. При определении материалов, наиболее подходящих для использования фотобиоэлектрохимических системах, учитывали структуру энергетических уровней полупроводника и чувствительность к свету $в$ видимой области спектра. Проведен сравнительный анализ для различных типов полупроводниковых материалов и определено, что для использования в фотобиоэлектрохимической системе лучше всего подходят Si, CdSe, CuInS $\mathrm{S}_{2} \mathrm{GaAs}, \mathrm{MoS}_{2}$ u TaNO, CdS, $\mathrm{Cu}_{2} \mathrm{O}, \mathrm{GaP}, \mathrm{C}_{3} \mathrm{~N}_{4}, \mathrm{SiC}$.

Ключевые слова: фотобиоэлектрохимическая система, экзоэлектрогены, кремниевый фотоэлемент, полупроводник, биоанод, запретная зона

L. Zubchenko, TF, ORCID 0000-0002-2549-3185

Ye. Kuzminskiy, Dr. Chem. Sc., Prof., ORCID 0000-0002-5632-8297 National Technical University of Ukraine "Igor Sikorsky Kyiv Polytechnic Inst
BIOELECTROCHEMICAL BACKGROUND OF PHOTOCATODE SELECTION FOR PHOTOBIOELECTROCHEMICAL SYSTEM

In recent years, the global warming and high pollution level on our planet force scientists to look for new renewable energy sources. Photobioelectrochemical systems are new environmental-friendly technology that uses microorganisms to produce electricity or hydrogen with simultaneous organic degradation. The article analyses the peculiarities of application of photoelectrochemical elements as a source of additional energy for the photobioelectrochemical system. The purpose of the work is to analyze photo- and bioelectrochemical processes occurring in photobioelectrochemical systems and the theoretical background of the material choice for the photoelectrochemical component of photobioelectrochemical systems, in terms of maximizing the overall system productivity. The specific feature of photobioelectrochemical systems deals with the fact that electrochemical reactions, occurring on the electrodes, have different nature and driving force, so, the productivity of the system always depends on many factors: working conditions, electrode material, the species of microorganism etc. The working principle of different types of photobioelectrochemical systems were reviewed. Bioelectrochemical and photoelectrochemical reactions, that occur in a four-electrode and two-electrode system were described as well as the flows of charge carriers that are involved in the formation of current in the system. The structure of the energy levels and the light sensitivity in the visible spectrum were taken into account for the choice of semiconductor. Based on comparative analysis of different types of semiconductor materials, Si, CdSe, CuInS $S_{2}$, $\mathrm{GaAs}, \mathrm{MoS}_{2}$ and TaNO, $\mathrm{CdS}, \mathrm{Cu}_{2} \mathrm{O}, \mathrm{GaP}, \mathrm{C}_{3} \mathrm{~N}_{4}$, SiC were determined to be the most suitable semiconductors for photocathode manufacturing in photobioelectrochemical systems.

Keywords: photobioelectrochemical system, exoelectrogens, photoelectrochemical cell, semiconductor, bioanode, forbidden zone

\section{References}

1 L. S. Zubchenko and Ye. V. Kuzminskyi, "Svitlozalezhne otrymannia vodnyu v palyvnyh ta biopalyvnyh elementah", Vidnovliuvalna enerhetyka, no. 4, s. 85-92, 2015. / Л. С. Зубченко, Є. В. Кузьмінський, “Світлозалежне отримання водню в паливних та біопаливних елементах”, Відновлювальна енергетика, Вип. 4, с. 85-92, 2015.

2. F. F. Ajayi, K. Y. Kim, K.-J. Chae, M. J. Choi, S. Y. Kim, I. S. Chang, and I. S. Kim, "Study of hydrogen production in light assisted microbial electrolysis cell operated with dye sensitized solar cell" Int $J$ Hydrogen Energy, vol. 34, no. 23, p. 9297-9304, 2009.

3. F. F. Ajayi, K. Y. Kim, K. J. Chae, M. J. Choi, S. Y. Kim, I. S. Chang, and I. S. Kim "Optimization studies of bio-hydrogen production in a coupled microbial electrolysis-dye sensitized solar cell system", Photochem. Photobiol. Sci., vol. 9, no. 3, p. 349-356, 2010.

4 H. Wang, F. Qian, G. Wang, Y. Jiao, Z. He, and Y. Li, "Self-biased solar-microbial device for sustainable hydrogen generation", ACS Nano, vol. 7, no. 10, p. 8728-8735, 2013. 


\section{ISSN 1813-5420 (Print). Енергетика: економіка, технології, екологія. 2018. № 1}

5. Ye. V. Kuzminskyi, H. Ya. Kolbasov, Ya. Yu. Tevtul, and N. B. Holub, Netradytsiini elektrohimichni systemy peretvorennia enerhii. Foto-, termo-, ta biopalyvni element: navchalnyi posibnyk. Chernivtsi: Ruta, 2003. / Є. В. Кузьмінський, Г. Я. Колбасов, Я. Ю. Тевтуль, та Н. Б. Голуб, Нетрадиційні електрохімічні системи перетворення енергії. Фото-, термо- та біопаливні елементи: Навчальний посібник. Чернівці: Рута, 2003.

6. F. Qian, G. Wang, and Y. Li "Solar-driven microbial photoelectrochemical cells with a nanowire photocathode", NanoLett., no. 10, p. 4686-4691, 2010.

7. A. Lu, Y. Li, S. Jin, H. Ding, C. Zeng, X. Wang, and C. Wang, "Microbial fuel cell equipped with a photocatalytic rutile-coated cathode", Energy Fuels, vol. 24 (2), p. 1184-1190, 2009.

8. Q.Y. Chen, J. S. Liu, Y. Liu, and Y.H. Wang, "Hydrogen production on $\mathrm{TiO}_{2}$ nanorod arrays cathode coupling with bio-anode with additional electricity generation", J. Power Sources , no. 238, p. 345-349, 2013.

9. H. W. Kim, K. S. Lee, A. Razzaq, S. H. Lee, C. A. Grimes, and S. I. In, "Photocoupled bioanode: a new approach for improved microbial fuel cell performance", Energy Technol., vol. 6, p. 257-262, 2018.

10. S. H. Lee, K. S. Lee, S. Sorcar, A. Razzaq, C. A. Grimes, and S. I. In, "Wastewater treatment and electricity generation from a sunlight-powered single chamber microbial fuel cell", J. Photochem. Photobiol., A, $9 \mathrm{p}, 2017$.

11. Kuzminskiy Ye., Shchurska K., Samarukha I., Lagod G., Bioelectrochemical hydrogen and electricity production. Theoretical bases, description and modeling of the process. Lublin: Politechnica Lubelska, 2013.

12. V. P. Hlushko, Termicheckie konstanty veshchestv, Moskva: VINITI, vol. 1-10, 1965-1982. I В. П. Глушко, Термические константы веществ. Москва: ВИНИТИ, т. 1-10, 1965-1982.

13. J. Yan Handbook of clean energy systems vol. 5. Chichester: John Wiley \& Sons, 2015.

14 B. E. Logan, B. Hamelers, R. Rozendal, U. Schröder, J. Keller, S. Freguia, P. Aelterman, W. Verstraete, and K. Rabaey "Microbial fuel cells: methodology and technology", Environ. Sci. Technol., vol. 40 (17), p. 51815192, 2006.

15 K. Rabaey, N. Boon, M. Höfte, and W. Verstraete, "Microbial phenazine production enhances electron transfer in biofuel cells", Environ. Sci. Technol., vol. 39 (9), p. 3401-3408, 2005.

16. A. Price-Whelan, L. E. P. Dietrich, and D. K. Newman, "Pyocyanin alters redox homeostasis and carbon flux through central metabolic pathways in Pseudomonas aeruginosa PA14", J. Bacteriol., vol. 189, no.17, p. 6372-6381, 2007.

17. L. E. P. Dietrich, A. Price-Whelan, A. Petersen, M. Whiteley, and D. K. Newman, "The phenazine pyocyanin is a terminal signaling factor in the quorum sensing network of Pseudomonas aeruginosa", Mol. Microbiol., vol. 61(5), p. 1308-1321, 2006.

18. J. Zhao, X. Wang, Z. Xu and J. S. C. Loo, "Hybrid catalysts for photoelectrochemical reduction of carbon dioxide: a prospective review on semiconductor/metal complex co-catalyst systems, J. Mat. Chem. A., vol. 2, Is. 37, p. 15228-15233, 2006.

19. М. М. Мусієнко та ін. Екологія: Тлумачний словник. Київ, Україна: Либідь, 2004. / M. M. Musiienko et al., Ekolohiia: Tlumacjnyi slovnyk. Kyiv, Ukraina: Lybid, 2004.

20. D. M. Frezi, V. M. Chobaniuk, M. O. Halushchak, O. S. Krynytskyi, and H. D. Mateik, "Fotoelectrychni peretvoriuvachi soniachnoho vyprominiuvannia. Dosiahnennia, suchasnyi stan i tendentsii rozvytku", Pizyka i himiia tverdoho tila, vol. 13, no. 1, s. 7-20, 2012. / Д. М. Фрезі, В. М. Чобанюк, М.О.Галущак, О. С. Криницький, та Г. Д. Матеїк, “Фотоелектричні перетворювачі сонячного випромінювання. Досягнення, сучасний стан і тенденції розвитку”, Фізика і хімія твердого тіла, т. 13, №1, c. 7-20, 2012.

21. V.P. Kozhemiako, O.H. Dombrovskyi, V.F. Zherdetskyi, V.I. Malinivskyi, and H.V. Prytuliak, "Analitychnyi ohliad suchasnyh technolohii fotoelektrychnyh peretvoriuvachiv dlia soniachnoi enerhetyky", optyko-elektronni informitsiino-enerhetychni technolohii, vol. 22, no. 20, s. 141-157, 2011. / В. П. Кожем 'яко, О. Г. Домбровський, В.Ф. Жердецький, В.І.Маліновський, та Г.В.Притуляк, “Аналітичний огляд сучасних технологій фотоелектричних перетворювачів для сонячної енергетики”, Оптико-електронні інформаційно-енергетичні технологіï, т. 22, №20, с. 141-157, 2011.

Надійшла 16.03.2018

Received 16.03.2018 